\title{
Uncovering Undergraduate English-as-a-Foreign-Language Learners' Perceptions of Reticence
}

\author{
Abbas Zare-ee (Corresponding author) \\ English Department, University of Kashan, Kashan, 87317-51167, Iran \\ E-mail: Zare-ee72@kashanu.ac.ir \\ Maryam Shirvanizadeh \\ English Department, Faculty of Arts and humanities, University of Kashan
}

Doi:10.7575/aiac.alls.v.5n.5p.50

URL: http://dx.doi.org/10.7575/aiac.alls.v.5n.5p.50
Received: 17/06/2014

Accepted: 15/08/2014

\begin{abstract}
The study of factors influencing undergraduate learners' participation and/or reticence in second/foreign language classrooms, a relatively recent line of research, can contribute to the betterment of language teaching and learning practices. In this work, we attempt to investigate the causes of a population of undergraduate English as a foreign language (EFL) learners' reticence by focusing on their own perceptions and by seeing the problem from their perspective. 201 male and female undergraduate Iranian EFL learners selected randomly based on Krejcie and Morgan's formula for determining sample size served as the participants of the study. The data were collected through interviews, observations and a five-point Likert-scale researcher-made questionnaire. The results of the analyses of the data through qualitative content-based coding of the transcripts, frequency counts, and factorial analysis of the questionnaire responses revealed the following: a) based on systematic class observations, most students appeared to understand teachers' instruction, took notes, and spoke when addressed; however, they rarely asked questions or volunteered responses; b) unfriendly and competitive class atmosphere, boring and useless topics and materials, and having unmotivated and serious teachers were among the most frequent learner-perceived factors causing reticence; c) based on the results of exploratory factorial analysis, 12 factors including learner anxiety, poor class management, peer/ teacher correction, background knowledge, grouping learners, and self-image were reported as the main causes of reticence. Based on these findings, we make suggestions for EFL teachers about how to consider students' concerns and to promote class participation.
\end{abstract}

Keywords: Class participation, Learner-centeredness, Reticence, English Language Teaching, Engagement, TEFL

\section{Introduction}

Participation in class has abundant advantages for learners of a language as it can help them test out their hypotheses about the language they are learning. It can also give them the chance to learn through involvement. The more utterances the learners offer, the better their spoken language is and vice versa (Hamouda 2012). Class participation can influence students' learning and their academic performance, a rise in their grades as found by various researchers (Liu 2005; Kimiko Futija 2005; J. Coldwell, et al 2008). Learners' reluctance to talk and to participate is not a problem of Iranian EFL learners. Many other university language lecturers are facing this problem as reflected by the concern of the reseaerchers. Students' reticence and silence in class may have different reasons and can be viewed from different aspects. This study aims at understanding the student's perceptions and opinions about their own class participation in order to get insights about the kind of activities and personal motivating and debilitating factors that may contribute to their success or lack of success in class.

A principal factor in university English classes which can create a friendly, motivating and useful environment for students is their participation in class. Through this participation, students experience different kinds of interactions between their friends, and their teachers. In this way students can feel relaxed and imagine that they are a crucial member of class community. Before any steps can be taken to encourage participation in class, the reason of students' reticence should be investigated.

Cognitive, pedagogical, situational and cultural factors have been attributed to students' silence in a number of studies. Among these reasons, students' fears of losing face, low English proficiency, anxiety and lack of self-confidence have been mentioned frequently. A glance at this issue and the clash that it has with the great enthusiasm of EFL learners for learning English in universities motivated this study. The other concern was the role of teacher/faculty members in preventing students to talk and to actively participate! Auster \& McRone, (1994) asserted that 'so far we have had little systematically collected empirical data on the impact of faculty members' behavior on students' participation.' (p. 289). Therefore, this study aimed at finding answers to one main question: what are the perceptions of undergraduate EFL learners about their classroom participation and reticence? 


\section{Literature Review}

For the word participation or engagement, different definitions have been mentioned in various studies. The study of engagement is hindered by lack of consensus in both the number of subtypes and definitions of student engagement (Christenson, Reschly \& Wylie, 2012). Generally there are two types of participation in a classroom: verbal and nonverbal. Verbal communication is a kind of communication through which one expresses himself/ herself in words and orally rather than in written form whereas non-verbal communication includes behavior and other elements of speech other than uttered words. The kind of class participation which will be examined in this study will focus primarily on verbal participation, although some instances of nonverbal participation such as taking notes will be investigated as well. The importance of class participation and student engagement has been supported in literature at both school and university level. A handful of researches have emphasized the effect of student engagement on academic achievement and high school graduation (Reynolds, 2001; Schweinhart \& Weikart, 1999), or on drop-out prevention (Davis and Graff ,2005;Liu 2005; Christenson et al., 2001; Dynarski \& Gleason, 2002). A study done by Castrillòn Ramírez (2010) about student's perception of their oral skills showed that students were highly aware of the importance of active participation for improving their oral skills. The findings revealed that more than half of the students took part in class discussions and activities with instrumental motivation for getting higher grades in class and grade was one of the most important factors for students' participation. On the other hand some of the students had integrative motivation and expressed their goal for participation as improving their communicative and oral skills.

Another aspect of students' participation is the existing relationship between participation and motivation. A number of researchers have used these two terms interchangeably (e.g., Martin, 2007; National Research Council, 2004) and others believe that they are completely distinct and separated. In the literature done, there are several studies that investigated the factors affecting students' participation in online courses. In this type of participation students don't have any physical or face-to-face contact with each other and they will be able to take part in courses from different backgrounds and places without any limitations of time and place. it's interesting to state that Caspi et al. (2006) argued that in comparison to students' participation in web-structured environments whether synchronous or asynchronous, students' participation in face-to-face courses or in a real class was much higher while Ya Ni (2012) in her study concluded that the quality and quantity of interaction was much higher in e-learning environments. The present study focuses on the face-to face participation of students in the typical University EFL classrooms of Iran.

In the following paragraphs, a quick review of main factors highlighted in previous research on EFL learners' reticence is offered. Each of the factors is complex in itself and a continuum rather than a clear-cut distinction can usually better depict what affect reticence. Personality type is the first factor. Some researchers attributed students' non-participation to their personality types, whether extrovert or introvert. In definition extroverts prefer communication and group activities while introverts are shy and aren't good communicators in class. Galvan and Fukada (1997/1998 as cited by Lee, 2005) showed that extrovert students had high participation in class while introverts' were least likely to initiate a question or to volunteer an answer to a teacher's question'. Interestingly Lee (2005) found no correlation between student personality type and participation but a significant correlation between students' cultural background and their participation, their length of stay in the United States, gender of students and the extent of English used outside of class. Anver Caspi, et al. (2006) also did their research based on the personality factors and their influence on social participation in learning environments. The main difference of this research with others was that the researchers examined students' participation in two different educational environments; namely, Web-based instructional environment (WBIE) and instructional environment.The findings revealed that students participated in class much more than in WBIE.

A second factor which influences students' reticence and specifically participation in speaking activities is students' anxiety. Horwirz, E. K., et al (1986) classified the causes of foreign language anxiety into three main components: communication apprehension, test anxiety and fear of negative evaluation. Gregerson, T., (2003) stated that anxious learners suffered from mental blocks during spontaneous speaking activities, lacked confidence, were less able to selfedit and were more likely to employ avoidance strategies such as skipping class. Anxiety has been recognized as a principal factor in many studies (e.g., Hamouda , 2012; Léger \& Storch, 2009; Tsiplakides, 2009; Ramírez, 2010; Ampadu, 2011; liu, 2007). Other studies such as the research done by Wu (2010) explored how Taiwanese students perceived the relationship between their language learning strategy and anxiety in the foreign language classroom. Learners had a favorable attitude toward CLT classes and unfavorable attitudes toward grammar translation method and hence experienced a lot of anxiety.

Culture can also be relevant to the level of student participation. Xie (2009) focused on Chinese students' 'cultures of learning' and their values and beliefs about a good learning situation. In this study teachers' interactional features was taken into consideration for investigating Chinese student's passivity in class. According to Xie this research was based on the sociocultural theory of Vygotsky (1978). According to vygotskey "cognitive development originates in social interaction, and in classroom settings learning occurs through interaction mediated primarily by speech in the learner's zone of proximal development (ZPD)", and maintained that teachers could establish friendly and inspiring environments by paying attention to student's cognitive and affective factors and through interaction with their students, help them to achieve to a higher levels of development.

Findings of previous studies report a negative relationship between shyness and classroom performance. As the shyness of an individual increased, classroom performance was known to decrease in an interesting study of the topic (Christenson, Reschly \& Wylie, 2012). Jackson (2001) and Trent (2004) both took the case of Chinese students into 
consideration and found that Chinese students had a tendency to be as reticent as possible, and had limited English language proficiency. Jimmy Tong (2010) in his research believed that students were ready to express their opinions at some other time, while they were passive and quiet at the beginning of field work period. Actually in this study a range of factors such as student effect, language proficiency and immediate pedagogical contexts were attributed to the Asian students' quietness and willingness to communicate orally.

Most researchers focused on the cultural factors in the study of reticence. The main difference of Xia Saihua's research (2009) from previous studies was the revealed role of cognitive and situational factors such as linguistic or psychological on the East Asian students' reticence rather than cultural factors. Following this study Cameron (2012) divided the factors into two categories of stable individual differences or trait and dynamic situational. Crombie \& et al (2003) investigated the effect of of individual and contextual factors on students' assessments of their own participation and of their professors' classroom behaviors. Researchers classified class size, class composition in terms of gender balance, discipline, gender of the instructor and specific instructor behaviors that encourage participation in contextual factors, whereas student gender, age, and students' perceived level of general activity in the university classroom were related to the individual factors. According to the results of the study active male students participated more than active female students and among $64 \%$ of the students who weren't active, Gender didn't differ. Older students participated more actively than younger students. Furthermore, Female students who had male instructors had a less favorable impression of their instructors. Active students had more positive perceptions toward their instructors' behavior as well.

Apart from contextual factors examined by Crombie \& et al (2003), Hanrahan M. (1998) investigated the effect of learning environment factors on students' motivation and learning. She took the constructivism approach and its theories such as metacognition, conceptual change, and the social construction of meaning to conduct her research. Hanrahan witnessed a high intrinsic and extrinsic motivation among students but they weren't satisfied with teacher-centered classes, and wished to have some autonomy in class. Above all students didn't have the same opportunity to participate in class and should wait to be called on in class.

Many early researchers investigated the issue of reticence from the learner's perspective, but Donald (2010) in his article examined the cause of student's reticence not only from learners' perspective, but also from the perspective of teachers. The main difference was the investigation of learners' perceptions in terms of two practices employed by teachers; namely, error correction and extended wait time. Findings revealed that learners' reticence was largely determined by the pedagogical strategies adopted by the instructor. In another research, Kim (2007) pointed to raising questions and participating in whole class discussion as the two most frequently expected oral tasks in graduate courses. The purpose of this study was to explore the perceptions of EAGS's (East Asian international graduate students) academic oral communication needs and verbal participation in U.S. graduate courses. According to the results EAGS diagnosed raising questions and participating in whole-class discussions as the two most frequently expected oral tasks in graduate courses and considered listening comprehension and participation as the most important skills for academic success, and pronunciation and note-taking as the least important. Açıkgöz also (2005) emphasized the importance of 'subject' factors, 'school' factors, 'teaching methods' factors, and teachers' personal factors on pupils' attitude toward learning. Above all Zhang and Head (2002) investigated the concept of "negotiated syllabus" which was determined jointly by teacher and students so as to improve their learners' confidence and ability to speak English by involving them in making decisions about the content and organization of their oral language classes.

The attention given to teachers' practices for encouraging students' class participation was also reflected in a study done by Mack L. (2012). She designed her study based on critical and constructivist pedagogy. According to these pedagogies, students learned to use their live experiences for analyzing the world around them and constructed their own ideas and meanings through discussion and group work. Through this critical action research "students become active participants in the project and are involved in the process of creating the action plan/intervention." (p.421). Teacher methodology, social inclusion and students' voice was reported as the main factors influencing student participation in class. Furthermore the researcher asserted that cultural characteristics and linguistic ability didn't play a significant role in enhancing participation. Students' reticence in the context of this study is sometimes attributed to to teachers' inappropriate teaching method, not suitable textbooks, and lack of CLT method in which teachers foster a community for students to collaborate, share and express their ideas in class. Razmjoo (2007) as cited by Assadi Aidinlou.N and Ghobadi.S (2012) believed that 'CLT method was not utilized in high schools because of the inadequacy of the government produced textbooks'. Similarly In another study Riasati (2012) identified task type, topics of discussion, interlocutor, teacher, class atmosphere, personality, and self-perceived speaking ability among the reasons for students reluctance and unwillingness to speak in Iran universities. Assadi, Aidinlou, and Ghobadi (2012) investigated the role of educational, social and student factors on students' oral participation and noted that educational factors 'are a better indicator of oral participation. At the university level especially EFL classes, students come to class with varying degrees of integrative and instrumental motivations. Other than factors mentioned above, motivation can play a significant role on students' participation in class. Vaezi (2008) as cited by Assadi Aidinlou.N and Ghobadi.S (2012) discovered that undergraduate university students had a high instrumental motivation to learn English. This study aimed at understanding the student's perceptions of and opinions about their class participation in order to get insights about the kind of activities and personal motivating and debilitating factors that may contribute to their success or lack of success in class. 


\section{Methodology}

\subsection{Participants}

At the outset of the study 201(46 male and 155 female) university EFL learners in Isfahan province volunteered to take part in the study. More than $77 \%$ of the respondents were female EFL learners. Anonymity for our informants was important and they were asked just to write down their gender and year of study. All of these learners were studying English Translation or English as a Foreign Language (EFL) at B.A level. Their ages ranged from 18-35 years old. The level learners' English proficiency was quite heterogeneous due to their different learning experiences Out of 201 students filling in the questionnaire, 23 students (12 male and 11 female) volunteered to be interviewed.For determining the sample size needed to be representative of a given population, the table of determining sample size for research activities designed by Krejcie and Morgan (1970) was used. As we wanted to collect the data from two Universities, the total number of Undergraduate EFl learners was reported to be 420. Hence based on this table 201 Iranian students both male and female should participate to fill out a questionnaire on their perceptions about class participation.

\subsection{Instruments}

In order to collect the research data, different instruments were used.In order to measure the EFL learners' perceptions a questionnaire was designed according to the results obtained from Green's study (2008). Moreover some of the questions were retrieved from interview psychological tests of anxiety and self-confidence. For the sake of a complete comprehension of the questionnaire and due to class heterogeneity, the questions were translated into Persian. In so doing all the students whether freshman, sophomore, junior or senior and with different degrees of English proficiency could be able to answer the questions without any concern. The questionnaire also included 10 general demographic questions regarding EFL learners' gender, age, year of education, major, college, course name, time of class, and last term GPA (grade point average). Another question was about whether EFL learners had attended any institute to learn English or they had had any familiarity with it. In question number 10 students rated their proficiency level in four English skills: listening, speaking, reading and writing. The purpose for using this type of question was the difference in the student's knowledge of English and was used as a self-assessment question. This could be helpful to see how students participate in class with different levels of English proficiency in their English courses. The questionnaire consisted of forty seven items written in a five-point Likert scale. For identifying the factors influencing students' participation, 3 instruments were used: questionnaire, interview and observation. The factors that students mentioned in the interview and open-ended questionnaire provided productive source of information for our present study. As the researcher and the independent rater analyzed the interview and the open-ended questionnaires, clear categories of factors influencing class participation emerged - both factors that inhibited and factors that encouraged participation in class. For obtaining the reliability of the whole questionnaire, an English class with the total of 35 students was selected randomly. The students of that class were given a questionnaire and the data gathered. The reliability gained (0.89) was calculated using Cronbach's alpha formula. Moreover, to ensure the validity of the questionnaire, three faculty members of Kashan University confirmed that the items inserted exactly assess the debilitative and facilitative factors for students' reticence in class.

Eight different English classes in two Universities were also observed as part of data collection. The classes were selected on a convenient sampling basis. The observation form was divided into parts: the main part included some questions regarding teachers' behavior and what activities the teacher utilized to engage students in the class activities and to increase their participation. The second part focused on the students' behavior and how they reacted to teachers' action in class and how much they attempted to be active learners. Furthermore all of the classes were observed for three times and at the end of the third session, the observation form was filled out based on the overall impression that each class gave us. Each observation took about one hour and half. The observation checklist was the Community College Survey of Student Engagement or CCSSE. Since the CCSSE observation form only focused on the EFL learners' behavior in class, it was modified and some questions regarding the participation of the students and their effort to be active in class were added. Finally the classrooms' observation form was divided into two separate parts. The first part focused on the lecturers' behavior and included 14 questions to be observed and the second part focused on the EFL learners' behavior and included eight questions. All the items were presented in a four-point Likert Scale. A semi-structured interview was used that included 6 open-ended questions to be asked from 23 participants who volunteered. This interview was conducted to gain a deeper understanding of students' perceptions and experiences concerning their classroom participations in undergraduate courses across the curriculum. The interview questions were derived from the open-ended questionnaire of Green (2008). The survey asked about the following: (a) Students' perceptions about the meaning of active class participation; (b) factors inhibiting their participation in class; (c) The factors motivating their participation in class; (D) Any difference between their level of participation in classes of their mother tongue and their level of participation in English classes; and (E) teacher-related characteristics which increase students' participation.

\section{3 procedures}

First a semi-structured interview with some participants in different English classes was conducted. This interview lasted about 20 minutes and finally the data was recorded and transcribed for further analysis. This interview was the basis for research questionnaire. Since not all EFL learners had the same English proficiency, the interview and questionnaire questions were translated into Persian.Before the class started, the time and duration of the data collection process were managed with the lecturers of each course. All lecturers consented that the questionnaires both for students and the lecturers be distributed at the end of the class. The participants were given time to tick the items in a rating 
scale in their own class time. This procedure took about 15 minutes. Furthermore, 8 different EFL classes were chosen conveniently and observed by the permission of the related instructors. The observed classes' data provided valuable data for the amount of students' participation in EFL classes.

\section{Results}

Having gathered the data based on the mentioned data collection instruments and procedures, the researchers analyzed the data for the present study. Observations in undergraduate EFL classes revealed interesting points. As Shown in Table 1, in eight observed classes, it was witnessed that students of five classes $(62.5 \%)$ made comments and gave their own opinion in class about the subjects raised. Moreover in (87.5\%) of classes students were observed they adequately asked the instructor/ students questioning during class. In (75\%) of classes, I observed that students adequately answered questions from other students or from teacher. This happened when the teacher was waiting for a kind of question to be asked from him/her or from other students. In five classes about (62.5\%) students adequately understood teacher's instructions or the materials to be read or listened to and volunteered answers in class. In these classes students were at some time confused and asked their fellow students for more explanation or elaboration of the subject. They also adequately answered questions voluntarily when they felt that it's necessary for them to show up in class. Furthermore as it can be seen in the table, only in one class about (12.5\%) students were observed minimally asking the instructor or students questions during the class time and made comments and gave their own opinions regarding the subject of study.

It was observed that teachers were completely prepared for teaching the subject; they all had a preplanned syllabus and follow that step by step during the class time. In six classes including $75 \%$ of the sample, teachers explained concepts clearly so that all the students could understand the contents of the course, showed enthusiasm for the subject matter and teaching, encouraged questions and students' participation, gave students an adequate amount of time to respond to questions and listened fully to students without interrupting or criticizing them. In five classes $(62.5 \%)$ teachers didn't ask students to speak without any preparation and interacted with individual students during the class session. Furthermore exactly half of the teachers ensured that students were engaged in the learning activities planned for the class session, and created an engaging and supportive learning experience during the observed class session. Surprisingly five teachers out of eight didn't interact with students working in small groups during the class session. This can show us that most of the teachers in class don't take group work into consideration very much. In all of these classes a kind of teacher-centered class was witnessed.

Table 1. Observed EFL learners' and lecturers' behavior

\section{EFL lecturers' behavior in class}

\begin{tabular}{|c|c|c|c|}
\hline$\frac{\Omega}{\stackrel{2}{2}}$ & 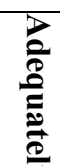 & 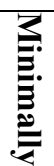 & $\begin{array}{l}Z \\
\stackrel{Z}{0} \\
\stackrel{2}{7} \\
\triangleq\end{array}$ \\
\hline
\end{tabular}

\begin{tabular}{|c|c|c|c|c|}
\hline 1. Was prepared to conduct class. & $8100 \%)$ & 0 & 0 & 0 \\
\hline $\begin{array}{l}\text { 2. Ensured that students were engaged in the learning activities } \\
\text { planned for the class session. }\end{array}$ & $4(50 \%)$ & $3(37.5 \%)$ & $1(12.5 \%)$ & 0 \\
\hline $\begin{array}{l}\text { 3. Noticed when a student or students were not engaged and } \\
\text { took action to involve the students in the class activity. }\end{array}$ & $3(37.5 \%)$ & $2(25 \%)$ & $3(37.5 \%)$ & 0 \\
\hline 4. Explained concepts clearly. & $6(75 \%)$ & $2(25 \%)$ & 0 & 0 \\
\hline 5. Showed enthusiasm for the subject matter and teaching. & $6(75 \%)$ & $2(25 \%)$ & 0 & 0 \\
\hline 6. Encouraged questions and students' participation. & $6(75 \%)$ & $2(25 \%)$ & 0 & 0 \\
\hline $\begin{array}{l}\text { 7. Gave students an adequate amount of time to respond to } \\
\text { questions. }\end{array}$ & $6(75 \%)$ & $2(25 \%)$ & 0 & 0 \\
\hline $\begin{array}{l}\text { 8. Provided feedback that gave students direction for } \\
\text { improvement. }\end{array}$ & $3(37.5 \%)$ & $5(62.5 \%)$ & 0 & 0 \\
\hline 9. Interacted with individual students during the class session. & $5(62.5 \%)$ & $1(12.5 \%)$ & $2(25 \%)$ & 0 \\
\hline $\begin{array}{l}\text { 10. Interacted with students working in small groups during the } \\
\text { class session. }\end{array}$ & $1(12.5 \%)$ & $1(12.5 \%)$ & $1(12.5 \%)$ & $5(62.5 \%)$ \\
\hline $\begin{array}{l}\text { 11. Used techniques that reflect an awareness of different } \\
\text { learning styles. }\end{array}$ & 0 & $2(25 \%)$ & $5(62.5 \%)$ & $1(12.5 \%)$ \\
\hline $\begin{array}{l}\text { 12. Created an engaging and supportive learning experience } \\
\text { during the observed class session. }\end{array}$ & $4(50 \%)$ & $4(50 \%)$ & 0 & 0 \\
\hline $\begin{array}{l}\text { 13. Listened fully to students without interrupting or criticizing } \\
\text { them. }\end{array}$ & $6(75 \%)$ & $2(25 \%)$ & 0 & 0 \\
\hline 14. Didn't ask students to speak without any preparation. & $5(62.5 \%)$ & $2(25 \%)$ & $1(12.5 \%)$ & 0 \\
\hline 20. made comments and gave their own opinion & $5(62.5 \%)$ & $2(25 \%)$ & $1(12.5 \%)$ & 0 \\
\hline $\begin{array}{l}\text { 15. Discussed class subject material or did activities in small } \\
\text { group class time. }\end{array}$ & $3(37.5 \%)$ & $3(37.5 \%)$ & $2(25 \%)$ & 0 \\
\hline $\begin{array}{l}\text { 17. Understood teacher's instructions or the materials to be read } \\
\text { or listened to. }\end{array}$ & $3(37.5 \%)$ & $5(62.5 \%)$ & 0 & 0 \\
\hline
\end{tabular}




\begin{tabular}{lllll}
\hline 22. Took notes during class. & $3(37.5 \%)$ & $3(37.5 \%)$ & $2(25 \%)$ & 0 \\
\hline 19. Answered questions from other students/ teacher. & $2(25 \%)$ & $6(75 \%)$ & 0 & 0 \\
\hline 21. Prepared to take part in class discussions. & $1(12.5 \%)$ & $4(50 \%)$ & $3(37.5 \%)$ & 0 \\
\hline 16. asked the instructor/ students questions during class. & 0 & $7(87.5)$ & $1(12.5 \%)$ & 0 \\
\hline 18. Volunteered answers in class. & 0 & $5(62.5 \%)$ & $3(37.5 \%)$ & 0 \\
\hline
\end{tabular}

The results of the interview with the learners about how they viewed participation also revealed interesting results. The interview included 5 main questions to be asked from 23 students. The results in table two show the findings for one of the interview questions: What does "active classroom participation" mean to you?

Table 2. Frequency and Percentage of EFL Learners' Definitions of Active Classroom Participation.

\begin{tabular}{|c|c|c|c|c|c|}
\hline \multirow{2}{*}{ 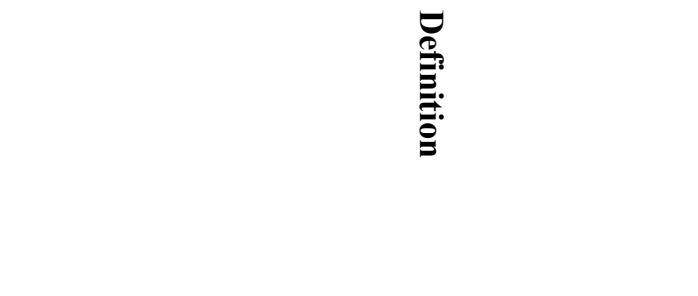 } & \multicolumn{2}{|c|}{ Yes } & \multicolumn{2}{|l|}{ No } & \multirow{2}{*}{ 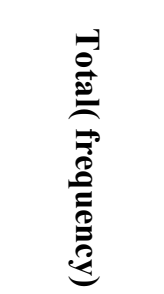 } \\
\hline & $\frac{3}{8}$ & 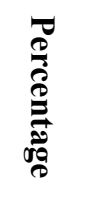 & $\begin{array}{l}3 \\
\frac{8}{3} \\
\frac{3}{3}\end{array}$ & 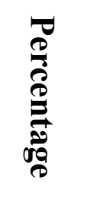 & \\
\hline 1) participating in class discussions & 16 & 69.6 & 7 & 30.4 & $23(100 \%)$ \\
\hline 2) question and answer milieu & 12 & 52.2 & 11 & 47.8 & $23(100 \%)$ \\
\hline 3) expressing ideas & 11 & 47.8 & 12 & 52.2 & $23(100 \%)$ \\
\hline 4) class preparation & 8 & 34.8 & 15 & 65.2 & $23(100 \%)$ \\
\hline 5) having presentations and suggesting new ideas & 7 & 30.4 & 16 & 69.6 & $23(100 \%)$ \\
\hline 6) class cooperation & 6 & 26.1 & 17 & 73.9 & $23(100 \%)$ \\
\hline 7) helping students of low English proficiency & 3 & 13.0 & 20 & 87.0 & $23(100 \%)$ \\
\hline 8) Students' mental and physical presence & 2 & 8.7 & 21 & 91.3 & $23(100 \%)$ \\
\hline 4) helping teacher to teach & 1 & 4.3 & 22 & 95.7 & $23(100 \%)$ \\
\hline 10) respecting ourselves and others & 1 & 4.3 & 22 & 95.7 & $23(100 \%)$ \\
\hline 11) doing class activities & 1 & 4.3 & 22 & 95.7 & $23(100 \%)$ \\
\hline 12) motivation & 1 & 4.3 & 22 & 95.7 & $23(100 \%)$ \\
\hline 13) paying attention to class & 1 & 4.3 & 22 & 95.7 & $23(100 \%)$ \\
\hline 14) being volunteer in class activities & 1 & 4.3 & 22 & 95.7 & $23(100 \%)$ \\
\hline
\end{tabular}

As it's obvious in this table, students introduced fourteen definitions for 'active class participation'. Participating in class discussions, question and answer milieu, expressing ideas, class preparation, having presentations and suggesting new ideas and class cooperation were among the definitions with high frequency in order. Below is a brief elaboration on each of these definitions.

Participating in class discussions: $16(69.6 \%)$ students believed that active participation means participating in class discussions. This number includes nearly half of the total population. According to students, in EFL majors the course should be taught completely in English since this provides them an opportunity not only to learn the subject of the course but also to improve their second language proficiencies. By the time the teacher discusses the topic in class, s/he expects students to take part in class discussion and express their ideas in class and share them with other classmates. Below are some examples of students who express their definition of active participation very well.

Well, for me, active classroom participation means a range of things, including group discussions or whole classroom discussions. Moreover, I sometimes start discussing some issues with the teacher himself (though this one is a little bit difficult). Indeed, the part that I like is starting a discussion and continuing it more than answering others' questions.

In my opinion, active classroom participation means to be fully engaged in classroom discussions, to ask questions, to express and share your ideas and to be involved in classroom interactions.

Question and answer milieu: $12(52.2 \%)$ students defined 'active participation' based on the questions posed by the teacher or students and the answers elicited in class. In every class there should be interaction between the faculty and 
students, with different forms. Students shouldn't be passive learners in class; rather they should be active during the whole session and ask their questions without being shy or afraid of being laughed by other students. EFL learners shouldn't leave the stage of teaching only to their teacher and expect him or her poses questions in class for students to answer, somehow students should dare to ask questions and force others to come up with an answer for that. In below students elaborate on their answers in a better way.

In my opinion, active participation means that students are ready to come up with an answer for teacher's question. I usually prefer that the teacher assigns all of us in group and asks to discuss the question with those sitting near us, and then asks for reports from various clumps of students around the room. By so doing I personally am not worried about not having any idea because I'm sure that at last our group will come up with a kind of answer.

For being an active participant I want our teacher to get all the students involved in the process of asking questions without any fear of criticism. Sometimes I have some questions in my mind but I avoid asking that because our teacher doesn't welcome it at all.

Expressing ideas: eleven students (including 47.8\%) voted for this definition. Delivering ideas and thoughts in an English class is an important aspect of communication. By expressing ideas they meant that the teacher should facilitate the class environment so that all students feel comfortable to speak up in class and to express their ideas clearly without being afraid of their possible wrong opinions.

Expressing your ideas clearly is a sign of active class participation. Some students really want to be an active student in class but unfortunately they fail to talk because of their hesitations. They are worry that some misunderstandings occur in class and others evaluate them wrongly.

I think those students who are always confident and comfortable enough to express their opinions in class are called active participants.

To express whatever you know about the subject of the class. In addition, trying to find what is new related to the subject and share it with other students.

Class preparation: 8 students (34.8\%) were of the opinion that active preparation means that all students should be completely prepared before coming to the class and they should be ensure to do the pre-reading early or preparing some questions to be asked about their misunderstandings.

Having presentations and suggesting new ideas: seven students (30.4\%) suggested that for being an active participant in class, students should volunteer to have lesson presentations in front of the whole class and even to introduce new activities, games and materials in class so as to change the repetitive and monotonous atmosphere in class. In so doing a kind of competitive environment creates in the classroom and lead passive students to be active and more engaged in class.

Class cooperation: six students (about 26.1\%) defined active participation as students' cooperation in class. This means that all the students should cooperate with each other or even with teacher. According to http://en.wikipedia.org/ Cooperative education or learning is the use of active participation methods in which students learn how to work together to solve problems, this is normally founded on the principles of children's rights, equality, equity and participation in decision-making. Its methods include game playing, expressing opinions, democratic participation, sharing, ensuring students all have an equal opportunity to take part, and conflict resolution. Other definitions including helping students of low English proficiency (13\%), students' mental and physical presence in class $(8.7 \%)$, helping teacher to teach $(4.3 \%)$, respecting ourselves and others $(4.3 \%)$, doing class activities $(4.3 \%)$, motivation and paying attention to class $(4.3 \%)$ gained a very low frequency among the respondents of the study. Results for a second interview question are summarized below in Table 3. In this table learners offer their views in response to the question "What factors inhibit your participation in class"?

Table 3. Results of Factors Inhibiting Students' Class Participation

debilitative factors

Yes

\begin{tabular}{llllll}
\hline 1) unfriendly and competitive class atmosphere & 12 & 52.2 & 11 & 47.8 & $23(100 \%)$ \\
\hline 2) boring and useless topics and materials & 9 & 39.1 & 14 & 60.9 & $23(100 \%)$ \\
\hline 3) having unmotivated and serious teacher & 8 & 34.8 & 15 & 65.2 & $23(100 \%)$ \\
\hline 4) physical and mental problems & 6 & 26.1 & 17 & 73.9 & $23(100 \%)$ \\
\hline 5) teacher's not encouraging students & 6 & 26.1 & 17 & 73.9 & $23(100 \%)$ \\
\hline
\end{tabular}




\begin{tabular}{llllll}
\hline 6) teacher's inappropriate behavior in class & 6 & 26.1 & 17 & 73.9 & $23(100 \%)$ \\
\hline 7) low English proficiency & 5 & 21.7 & 18 & 78.3 & $23(100 \%)$ \\
\hline 8) not having background knowledge & 5 & 21.7 & 18 & 78.3 & $23(100 \%)$ \\
\hline 9) not being prepared & 4 & 17.4 & 19 & 82.6 & $23(100 \%)$ \\
\hline 10) fear of evaluation & 3 & 13.00 & 20 & 87.00 & $23(100 \%)$ \\
\hline 11) too difficult or too easy course & 3 & 13.00 & 20 & 87.00 & $23(100 \%)$ \\
\hline 12) not having extracurricular activities & 3 & 13.00 & 20 & 87.00 & $23(100 \%)$ \\
\hline 13) poor class management & 3 & 13.00 & 20 & 87.00 & $23(100 \%)$ \\
\hline 14) time-constraints & 3 & 13.00 & 20 & 87.00 & $23(100 \%)$ \\
\hline 15) shyness & 3 & 13.00 & 20 & 87.00 & $23(100 \%)$ \\
\hline 16) inappropriate class time & 3 & 13.00 & 20 & 87.00 & $23(100 \%)$ \\
\hline 17) not having a knowledgeable teacher & 2 & 8.7 & 21 & 91.3 & $23(100 \%)$ \\
\hline 18) teacher's not accepting criticism & 2 & 8.7 & 21 & 91.3 & $23(100 \%)$ \\
\hline 19) studying for getting high scores & 2 & 8.7 & 21 & 91.3 & $23(100 \%)$ \\
\hline 20) anxiety & 2 & 8.7 & 21 & 91.3 & $23(100 \%)$ \\
\hline 21) low self-confidence & 2 & 8.7 & 21 & 91.3 & $23(100 \%)$ \\
\hline 22) having the same partner in groups & 2 & 8.7 & 21 & 91.3 & $23(100 \%)$ \\
\hline 23) sitting at the end of class & 1 & 4.3 & 22 & 95.7 & $23(100 \%)$ \\
\hline 24) being introvert & 1 & 4.3 & 22 & 95.7 & $23(100 \%)$ \\
\hline 25) not having group work & 1 & 4.3 & 22 & 95.7 & $23(100 \%)$ \\
\hline 26) teacher's not assigning a score to activities & 1 & 4.3 & 22 & 95.7 & 23 \\
\hline 27) class participation of a few students & 1 & 4.3 & 22 & 95.7 & 23 \\
\hline 28) being absent & 1 & 4.3 & 22 & 95.7 & 23 \\
\hline 29) class heterogeneity & 1 & 4.3 & 22 & 95.7 & 23 \\
\hline 30) teacher's poor methodologna & 1 & 4.3 & 22 & 95.7 & 23 \\
\hline
\end{tabular}

Based on the Data in Table 3, nearly half of the students about (52.2\%) believed that unfriendly and competitive class atmosphere is the most important factor which can inhibit them to participate actively in English classes. Other factors such as boring or useless topics and materials (39.1\%), having unmotivated and serious teacher (34.8\%), physical and mental problems (26.1\%), teacher's not encouraging students $(26.1 \%)$ and teacher's inappropriate behavior in class $(26.1 \%)$ were among the top four important factors mentioned in students' responses. On the other hand some factors such as not having a knowledgeable teacher (8.7\%), teacher's not accepting criticism (8.7\%), studying for getting high scores $(8.7 \%)$, anxiety $(8.7 \%)$, low self-confidence $(8.7 \%)$, having the same partner in groups $(8.7 \%)$, sitting at the end of class (3.4\%), being introvert(3.4\%), not having group work (3.4\%), teacher's not assigning a score to activities $(3.4 \%)$, class participation of a few students $(3.4 \%)$, being absent $(3.4 \%)$, class heterogeneity $(3.4 \%)$ and teacher's poor methodology (3.4\%) gained a low frequency among the respondents of the study.

The researchers were also interested to find out what in teachers inhibited students from participating. The result is Table 4 summarized the data collected in response to this question: "What characteristics are in an English teacher that may influence your class participation"?

Table 4. Characteristics in Teachers that Influence Students' Participation.

\begin{tabular}{|c|c|c|c|c|c|}
\hline \multirow{2}{*}{ characteristics } & \multicolumn{2}{|c|}{ Yes } & \multicolumn{2}{|c|}{ No } & \multirow{2}{*}{ 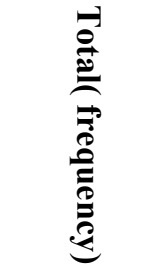 } \\
\hline & 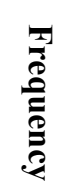 & 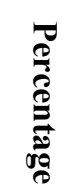 & 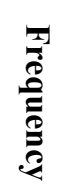 & 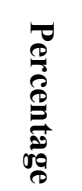 & \\
\hline 1) creating a secure and friendly atmosphere in class & 21 & 91.3 & 2 & 8.7 & $23(100 \%)$ \\
\hline 2) knowledge and ability & 9 & 39.1 & 14 & 60.9 & $23(100 \%)$ \\
\hline 3) encouraging students for participating in class & 9 & 39.1 & 14 & 60.9 & $23(100 \%)$ \\
\hline
\end{tabular}




\begin{tabular}{lccccc}
\hline 4) using a new and creative methodology & 7 & 30.4 & 16 & 69.6 & $23(100 \%)$ \\
\hline 5) encouraging discovery learning & 4 & 17.4 & 19 & 82.6 & $23(100 \%)$ \\
\hline 6) being energetic and motivated & 4 & 17.4 & 19 & 82.6 & $23(100 \%)$ \\
\hline 7) answering students' questions & 3 & 13.00 & 20 & 87.00 & $23(100 \%)$ \\
\hline 8) sense of humor & 3 & 13.00 & 20 & 87.00 & $23(100 \%)$ \\
\hline 9) respecting students' point of view & 2 & 8.7 & 21 & 91.3 & $23(100 \%)$ \\
\hline 10) showing sympathy & 2 & 8.7 & 21 & 91.3 & $23(100 \%)$ \\
\hline 11) having justice & 2 & 8.7 & 21 & 91.3 & $23(100 \%)$ \\
\hline 12) having commitment to teaching & 2 & 8.7 & 21 & 91.3 & $23(100 \%)$ \\
\hline 13) time management & 1 & 4.3 & 22 & 95.7 & $23(100 \%)$ \\
\hline 14) having high experience & 1 & 4.3 & 22 & 95.7 & $23(100 \%)$ \\
\hline 15) using technology in class & 1 & 4.3 & 22 & 95.7 & $23(100 \%)$ \\
\hline 16) use of discipline & 1 & 4.3 & 22 & 95.7 & $23(100 \%)$ \\
\hline 17) teacher's appearance & 1 & 4.3 & 22 & 95.7 & $23(100 \%)$ \\
\hline 18) being punctual & 1 & 4.3 & 22 & 95.7 & $23(100 \%)$ \\
\hline
\end{tabular}

As the table shows, 21 students including $(91.3 \%)$ of the whole population asserted that creating a secure and friendly atmosphere in class by teacher is an important characteristic which increases their class participation. Knowledge and ability (39.1), encouraging students for participating in class discussions (39.1), and using a new and creative methodology (30.4) are other teacher's characteristics enjoying a high frequency among students in a row. From the other hand and according to the table, only two students about $(8.7 \%)$ mentioned each of the following teachers' characteristics: respecting students' point of view, showing sympathy, having justice, and having commitment to teaching. Six other characteristics which were mentioned each only by one student include being punctual, teacher's appearance, use of discipline, using technology in class, having high experience, and time management.

In another main part of the data analysis, the proposed instrument (questionnaire) was analyzed through a principle component analysis and eigen values larger than 1.00 were used in the analysis as the default to check the factors underlying the 47 -item questionnaire data. 12 factors were finally extracted that can influence participation. Table 5 shows the relationships between these factor and reticence of the learners.

Table 5. The Correlation between Participation and Factors found in the questionnaire

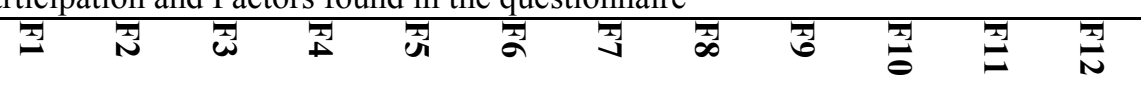

Active Participation

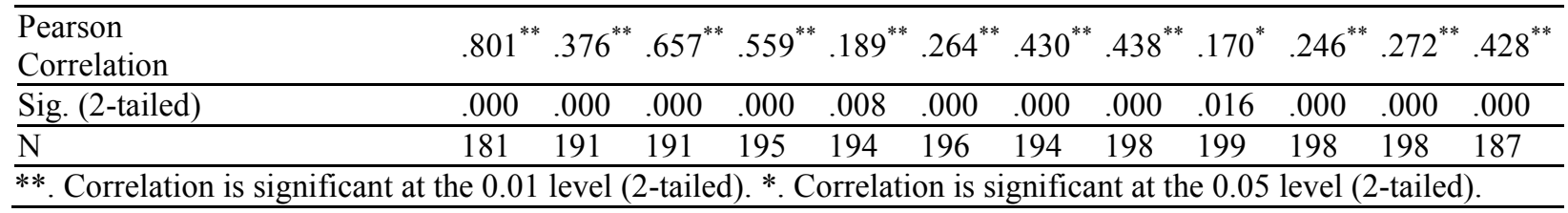

As table 12 displays, A Pearson product-moment correlation coefficient was run to determine the relationship between 201 students' active participation and the generated factors. Data yielding a $p$ value of $.000, .016, .008$ and .942 indicated that the active participation and the 12 factors were significantly correlated, with correlation coefficients ranging from .801 to .005 . The strongest correlation was between active participation and the first factor, students' anxiety to participate, $(\mathrm{r}=.801)$ and the weakest is for factor nine as labeled group work $(\mathrm{r}=170)$. It should be mentioned that the correlation between active participation and factor thirteen is not significant. $(\mathrm{r}(198)=.005, \mathrm{p}=$ .942). It means that teachers' criticism doesn't much affect students' class participation. This factor was omitted from the total list of factors along with their questions (table 9). As can be seen, the correlations between active participation and factors three, four, eight and seven are statistically and strongly significant in a row as well $(\mathrm{r}=657),(\mathrm{r}=.559),(\mathrm{r}=438)$, $(\mathrm{r}=.430),(\mathrm{p}=.000)$.

\section{Discussion}

The first question of the interview asked EFL learners about their definition of active class participation and its importance. Almost all of the students emphasized the highly influential role of engagement and participation on their academic success and their process of learning in class. This analysis is also supported by the studies of (Kim, 2007; Scepansky 2003; Green, 2008). The most frequent definitions elicited from students in this part include: participating in 
whole class discussions, expressing ideas, class preparation and cooperation, question and answer milieu, having presentations and suggesting new ideas. These findings are highly consistent with the studies of Green (2008) and Kim (2007). Kim found that EAGS (East Asian international graduate students), considered themselves as active when they verbally engaged with the class by asking or answering questions, exchanging opinions, initiating conversations, or sharing their own personal background relative to the discussion topic (p. 199). Moreover other definitions such as helping students of low English proficiency, Students' mental and physical presence, helping teacher to teach or motivation reported by minority of students in the present study can't be overlooked.

The second and third interview questions were productive sources of information for the identification of factors which might influenced EFL learners' participation in university English classes. As the students asserted in the interview, these two questions could help them diagnose the positive and negative factors which may influence their engagement in University classes. All the results mentioned below will be listed and discussed in order of distribution of mention. This means that categories are listed starting by those mentioned by most students and proceeding to those mentioned by few participants. According to the results nearly half of the learners believed unfriendly and competitive class atmosphere is the most important factor which could inhibit them to participate actively in English classes. Although this finding was mentioned in some previous researches as a negative factor but it wasn't recognized as the most important inhibiting factor. Other factors reported by learners included useless and boring topics, unmotivated teacher, physical and mental problems, teacher's not encouraging students, teacher's inappropriate behavior and attitude, students' low English proficiency and not having background knowledge. These factors were also echoed by other research findings (eg., Green, 2008; Meihua liu, 2007; John Trent, 2004; Jane Jackson, 2001; Crombie \& et al, 2003; Faizah Mohamad Nor \& Liew Hui Choo, 2008). However other factors such as not having extracurricular activities, anxiety, being introvert and teacher's poor methodology were ranked the lowest among EFL learners, but many studies including (Mack L., 2012; Galvan and Fukada (1997/1998 as cited by Lee, 2005; Caspi, et al. ,2006 ; Hamouda, 2012; liu , 2007; Rayfield et al. , 2008) strongly support their role on class participation.

The third research question mainly focused on factors which could increase students' participation in class. Similar to the results obtained from the previous question and previous researches supporting them, friendly class atmosphere, interesting and useful course and topics, teachers' paying attention to students and supporting them, having background knowledge and Teachers' creativity and using extracurricular activities were ranked as high among the other motivating factors. To sum up based on the interview findings, it may be safe to assume that most of the Iranian EFL learners are more concerned about teachers' establishing a friendly class atmosphere, providing interesting and useful topics and materials and activating their background knowledge before teaching in University English classes.

More than half of the respondents believed that participation and engagement in class was so essential due to the need to practice and develop their foreign language skills, especially speaking and to get higher grades (as Green calls a perceived value of participation). This is also completely consistent with Kim's study (2007) in which East Asian graduate students rated most oral communication skills as very important for their academic success in U.S. graduate courses, except note-taking skills and pronunciation. EAGS ranked having strong listening skills to understand formal lecture and participating in classroom discussions as the most essential skills and note-taking skills and good pronunciation as the least important skills (p.186).

On the other hand, Iranian EFL learners asserted that they were never concerned about the truth or falsehood of their answers for participation. They were self-confident enough to voice their opinions and ideas without fear of being wrong. Another positive point for students was that, they weren't afraid of being called up to speak in front of the class about something for which they aren't prepared. This finding is inconsistent with teachers' perceptions about students' reticence in class because it is always assumed that students get nervous and start to panic in situation for which they aren't prepared. In Greens' study (2008) teachers recognized students' preparation for class as a principal factor encouraging trainees to participate in class (p.20). However it worth mentioning that learners felt insulated and worried in case their classmates or their teacher point out their mistakes in class and threaten their face. This finding strongly confirms the results obtained in previous studies about anxiety and peer influence including (Green, 2008; Hamouda, 2012; Tsiplakides, 2009; Ramírez, 2010 ; Ampadu ,2011; Cubukcu ,2007). Another factor which was witnessed in learners' responses was known as sensitivity to others which Green defines it as comments referring to respect towards others, an understanding of others' wish to speak, a sense of fairness and companionship, and group spirit (p.20).

\section{Conclusion}

A thorough understanding of factors influencing students' participation will pave the way for both lecturers and students to consider their classroom setting and strategies used to engage learners. It seems few instructors foster a learnercentered class and encourage students to make large or small groups. Lecturers usually were prepared for teaching the subject, explained clearly, were enthusiastic for teaching, supportive of learners in the process of learning and teaching, helpful and encouraging, patient of students' mistakes and listened fully to students without interrupting or criticizing them. EFL lecturers were also witnessed to be self-confident, active participators, not shy, and volunteer to participate in the answer and question milieu. As Donald (2010) also asserted reticence on the part of the learner was largely determined by the pedagogical strategies adopted by the instructor, though this is not the sole factor that leads to reticence (p. 53). We hope learners and teacher get a better understanding of inhibiting factors causing reticence. 


\section{References}

Açıkgöz, F. (2005). A study on teacher characteristics and their effects on students' attitudes. The Reading Matrix, 5(2), 103-115.

Appleton, J. J., Christenson, S. L., \& Furlong, M. J. (2008). Student engagement with school: Critical conceptual and methodological issues of the construct. Psychology in the Schools, 45, 369-386

Aidinlou, N. A., \& Ghobadi, S. (2012). Examination of Relationships between Factors Affecting on Oral Participation of ELT Students and Language Development: A Structural Equation Modeling Approach. International Journal of English Linguistics, 2(5), p131.

Ampadu, E. (2011). Does Peer Influence Affect Students Participation in Mathematics?. International Online Journal of Educational Sciences, 3(2), 424-434.

Auster,C. J. \& MacRone, M. (1994) the classroom as a negotiated social setting: an Empirical study of the effects of faculty members' behavior on students' participation. Teaching Sociology, 22, 289-300.

Bergin, C. C., \& Bergin, D. A. (2011). Child and adolescent development in your classroom. Cengage Learning.

Cameron, D. (2012). Willingness to Communicte in English as a Second Language as a Stable Trait or Context-influenced Variable: Case Studies of Iranian Migrants to New Zealand. Auckland University of Technology

Caspi, A., Chajut, E., Saporta, K., and Beyth-Marom, R. (2006). The influence of personality on social participation in learning environments. Learning and Individual Differences 16, 129-144

Castrillón Ramírez, V. A. (2010). Students perceptions about the development of their oral Skills in an English as a foreign language teacher training program.

Chastain, k. (1988). Developing second-language skills: Theory and practice. (3rd ed., p286) Harcourt Brace Jovanovich, Inc.

Cheng, X. (2000). Asian students' reticence revisited. System, 28(3), 435-446.

Christenson, S., Reschly, A. L., \& Wylie, C. (2012). Handbook of research on student engagement. New York, NY: Springer.

Coldwell, J. Craig, A. Paterson, T. and Mustard, J. " Online students: relationships between participation, demographic and academic performance." the Electronic Journal e-learning Volume 6 issues 12008 (pp.19-30), online at www.ejel.org

Creswell, J. W. (2012). Qualitative inquiry and research design: Choosing among five approaches. Sage publications.

Crombie, G., Pyke, S. W., Silverthorn, N., Jones, A., \& Piccinin, S. (2003). Students' perceptions of their classroom participation and instructor as a function of gender and context. The journal of higher education, 74(1), 51-76.

Cubukcu, F. (2007). Foreign language anxiety. Iranian Journal of Language Studies, 1(2), 133-142.

Donald, S. H. A. N. E. (2010). Learning how to speak: Reticence in the ESL classroom. ARECLS, 7, 41-58.

Dynarski, M., \& Gleason, P. (2002). How can we help? What we have learned from recent federal dropout prevention evaluations. Journal of Education for Students Placed At-Risk, 7, 43-69.

Fujita, K. (2006). The effects of extracurricular activities on the academic performance of junior high students. Undergraduate Research Journal for the Human Sciences, 5(1).

Galvan, J., \& Fukada, Y. O. S. H. I. F. U. M. I. (1997). Asian international students' preferences for learning in American universities. The CATESOL Journal, 1, 29-49.

Green, D. (2008). Class participation in a teacher training college: What is it and what factors influence it. English Language Teacher Education and Development, 11, 15-26.

Gregerson, T. (2003). "To err is human: A reminder to teachers of language-anxious students". Foreign Language Annals 36 (1): 25-32.

Hamouda, A. (2012). An Exploration of Causes of Saudi Students' Reluctance to Participate in the English Language Classroom. International Journal of English Language Education, 1(1), pp-1.

Hanrahan, M. (1998). The effect of learning environment factors on students motivation and learning. International Journal of Science Education, 20(6), 737-753.

Horwirz, E. K.; Horwitz, M. B.; Cope, J. (1986). "Foreign Language Classroom Anxiety". The Modern Language Journal 70 (ii). 
Jackson, J. (2002). Reticence in second language case discussions: Anxiety and aspirations. System, 30(1), 65-84.

Kim, S. (2007). ACTIVE VERBAL PARTICIPATION IN US CLASSROOMS: PERCEPTIONS OF EAST ASIAN INERNATIONAL GRADUATE STUDENTS (Doctoral dissertation, The Ohio State University).

Krejcie, R. V., \& Morgan, D. W. (1970). Determining sample size for research activities. Educational and Psychological Measurement, 30, 607-610.

Lee, P. (2005). Students' personality type and attitudes toward classroom participation. In Proceedings of the CATESOL state conference (pp. 1-3).

Le'ger,D. \& Storch, N. (2009) Learners' Perceptions and Attitudes: Implications for Willingness to Communicate in an L2 Classroom. System 37 (2009) 269-285. Available online at www.sciencedirect.com

Liu, M. (2007). Anxiety in oral English classrooms: a case study in China. ANXIETY, 3(1).

Mack, L. (2012). Does every student have a voice? Critical action research on equitable classroom participation practices. Language Teaching Research, 16 (3), 417-434.

Nor, F.M., \& Hui Choo, L. (2008) an investigation into the factors affecting second language learners' classroom participation. Technology University of Malaysia.

Razmjoo, S. A. (2007). High schools' or private institutes' textbooks? Which fulfill communicative language teaching principles in the Iranian context? Asian EFL Journal, 9(4), 126-140.

Reynolds, A. J. (2001). Press release: Long-term effects of CPC program. Retrieved October 3, 2006, from http://www.waisman.wisc.edu/cls/PRESS01.PDF.

Riasati, M. J. (2012). EFL learners' perceptions of factors influencing willingness to speak English in language classrooms: A qualitative study. World Applied Sciences Journal, 17(10), 1287-1297.

Schweinhart, L. J., \& Weikart, D. P. (1999). The advantages of High/Scope: Helping children lead successful lives. Educational Leadership, 57(1), 77-78.

Tong, J. (2010). Some Observations of Students' Reticent and Participatory Behaviour in Hong Kong English Classrooms. Electronic Journal of foreign Language teaching, 7(2), 239-254.

Trent, J. (2009). Enhancing oral participation across the curriculum: Some lessons from the EAP classroom. Asian EFL Journal, 11(1), 256-270.

Tsiplakides, I., \& Keramida, A. (2009). Helping students overcome foreign language speaking anxiety in the English classroom: Theoretical issues and practical recommendations. International Education Studies, 2(4), P39.

Vaezi, S. (2007, November). Communicative language teaching: In the Middle East? Paper presented at the LED conference, Waikato University, Hamilton, New Zealand.

Vygotsky, L. S. (1980). Mind in society: The development of higher psychological processes. Harvard university press.

Wu, K. H. (2010). The relationship between language learners' anxiety and learning strategy in the CLT classrooms. International Education Studies, 3(1), p174.

Xia, S. (2009). Are they ready to participate? East Asian students' acquisition of verbal participation in American classrooms. Issues in Applied Linguistics, 17(2).

Xie, X. (2009). Why are students quiet? Looking at the Chinese context and beyond. ELT journal, ccp060.

$\mathrm{Ni}$, A. Y. (2013). Comparing the Effectiveness of Classroom and Online Learning: Teaching Research Methods. JPAEJOURNAL OF PUBLIC AFFAIRS EDUCATION VOLUME 19 NUMBER 2, 199.

Zhang, X., \& Head, K. (2009). Dealing with learner reticence in the speaking class. ELT journal, ccp018. 
Appendix: Classroom participation Questionnaire

\begin{tabular}{|c|c|c|c|c|c|}
\hline Classroom participation & 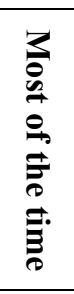 & $\stackrel{\ominus}{\stackrel{\rightleftarrows}{\rightleftarrows}}$ & 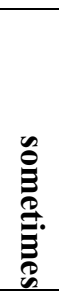 & $\frac{\overrightarrow{0}}{0.0}$ & $\begin{array}{l}\frac{1}{2} \\
\frac{1}{9}\end{array}$ \\
\hline \multicolumn{6}{|l|}{ 1) I have previous information and knowledge about the content of class. } \\
\hline \multicolumn{6}{|l|}{ 2) I have enough previous experience concerning the topic of study. } \\
\hline \multicolumn{6}{|l|}{ 3) I try to participate when I feel sure of my answers and ideas. } \\
\hline \multicolumn{6}{|l|}{ 4) I feel confident when I speak English in class. } \\
\hline 5) How I feel about myself is more important than others' opinions of me. & & & & & \\
\hline \multicolumn{6}{|l|}{ 6) I feel devastated when someone criticizes me in class. } \\
\hline \multicolumn{6}{|l|}{ 7) When I know the answer I don't dare to speak up in class. } \\
\hline \multicolumn{6}{|l|}{ 8) I participate less in classes with a large number of students. } \\
\hline \multicolumn{6}{|l|}{ 9) I'm afraid of making mistakes in front of classmates. } \\
\hline \multicolumn{6}{|l|}{ 10) When people point out my mistakes, I feel insulted. } \\
\hline \multicolumn{6}{|l|}{ 11) I'm afraid of being judged by my classmates } \\
\hline \multicolumn{6}{|l|}{$\begin{array}{l}\text { 12) I am afraid that my English teacher is ready to correct every mistake I } \\
\text { make. }\end{array}$} \\
\hline \multicolumn{6}{|l|}{ 13) I am afraid that the other students will laugh at me when I speak English. } \\
\hline \multicolumn{6}{|l|}{ 14) I feel relaxed in the activities that the teacher present in class. } \\
\hline \multicolumn{6}{|l|}{ 15) I'm interested in the topic and subject of our study. } \\
\hline \multicolumn{6}{|l|}{ 16) I can find the right word to express myself in English. } \\
\hline \multicolumn{6}{|l|}{$\begin{array}{l}\text { 17) I can understand my teacher's instructions or the materials to be read or } \\
\text { listened to. }\end{array}$} \\
\hline \multicolumn{6}{|l|}{ 18) I can speak fluently in class because I have good pronunciation. } \\
\hline \multicolumn{6}{|l|}{ 19) In our class, participation is so essential. } \\
\hline \multicolumn{6}{|l|}{ 20) I have to participate to practice and develop my foreign language skills. } \\
\hline \multicolumn{6}{|l|}{ 21) I'm an extrovert person. } \\
\hline \multicolumn{6}{|l|}{ 22) I tremble when I know that I'm going to be called on in class. } \\
\hline \multicolumn{6}{|l|}{$\begin{array}{l}\text { 23) I start to panic when I have to speak without preparation in the English } \\
\text { class. }\end{array}$} \\
\hline \multicolumn{6}{|l|}{ 24) It embarrasses me to volunteer answers in my English class. } \\
\hline \multicolumn{6}{|l|}{ 25) Even if I am well prepared for the English class, I feel anxious about it } \\
\hline \multicolumn{6}{|l|}{ 26) I feel that the other students speak English better than I do. } \\
\hline \multicolumn{6}{|l|}{ 27) I feel relaxed in group discussions. } \\
\hline \multicolumn{6}{|l|}{$\begin{array}{l}\text { 28) I feel embarrassed when I notice that other students have more knowledge } \\
\text { about the content. }\end{array}$} \\
\hline \multicolumn{6}{|l|}{ 29) I understand my friends wish to speak and let them start. } \\
\hline \multicolumn{6}{|l|}{$\begin{array}{l}\text { 30) I think it's fair to let my classmates participate and not always be the one } \\
\text { who participate in class. }\end{array}$} \\
\hline 31) I think that the class time is good and I can actively participate. & & & & & \\
\hline 32) My emotional and physical state influences my participation. & & & & & \\
\hline 33) The English class moves so quickly I worry about getting left behind & & & & & \\
\hline $\begin{array}{l}\text { 34) The teacher instruction is so transparent that I can understand what to do } \\
\text { in class. }\end{array}$ & & & & & \\
\hline
\end{tabular}


35) I get nervous when the English teacher asks questions which I haven't prepared in advance

36) It frightens me when I don't understand what the teacr is saying in English

37) Teacher often makes English class fun and interesting

38) My teacher is very organized and prepared for teaching the subject.

39) I feel satisfied with the teaching method of my English teacher

40) My teacher creates a supportive learning environment.

41) My teacher is very knowledgeable.

42) My teacher builds rapport with students.

43) My teacher doesn't continuously talk during discussions and let other students participate.

44) When speaking in class, my teacher doesn't criticize us for our mistakes.

45) My teacher gets all the students involved in discussions.

46) We discuss a lot in English either in pairs or in larger groups during lessons.

47) My teacher can manage the class well. 